14 June (Thursday)

FIELD TRIP

8:00 A.M.

Tour of the University of

Pittsburgh Map Library

Host, Bill Roselle, Director of

University Library System

Urban Rivers: De-industrial-

ization, Redevelopment

and the Three Rivers in

Pittsburgh.'

Dr. Edward Muller,

University of Pittsburgh

10:30 A.M.

Bus tour of Homestead,

Pennsylvania and South

Side Area

2:00 P.M.

Tour of Old Economy Village (Ambridge, PA) Historical

Museum

For additional information, contact: Mr. David McQuillan, Map Library (Cooper Library), University of South Carolina, Columbia, SC 29208, 803-777-4723.

\section{NACIS news}

\section{NACIS OFFICERS}

President: Diana Rivera, Map Librarian, Michigan State University Libraries, East Lansing, MI 48824; (517) 353-4593

Vice President: James F. (Fred) Fryman, Department of Geography, University of Northern Iowa, Cedar Falls, IA 50614-0406; (319) 273-6245

Treasurer: Gregory Chu, Department of Geography, University of Minnesota, 414 Social Sciences Building, Minneapolis, MN 55455; (612) 625-0892

Secretary: James R. Anderson, Jr., Florida Resources and Environment Analysis Center, Florida
State University, Tallahassee, FL 32306; (904) 644-2883

\section{NACIS EXECUTIVE OFFICER}

Ronald M. Bolton, NACIS, 6010

Executive Boulevard, Suite 100,

Rockville, MD 20852; (301) 443-

8075

\section{BOARD OF DIRECTORS}

Patricia Gilmartin, Department of Geography, University of South Carolina, Columbia, SC 29208; (803) 777-2989

Patrick McHaffie, Department of Geography, University of Kentucky, Lexington, KY 40506

Craig Remington, Department of Geography, University of Alabama, University, AL 35486; (205) 348-1536

Nancy Ryckman, Reference Department, 152 Jackson Library, University of North Carolina at Greensboro, Greensboro, NC 27412; (919) 334-5419

Johnnie Sutherland, Map Collection, Science Library, University of Georgia Libraries, Athens, GA 30602; (404) 542-0690

Ellen White, Department of Geography, Michigan State University, East Lansing, MI 48824; (517) 366-4658

\section{CARTOGRAPHIC PERSPECTIVES \\ Editor and Designer:}

David DiBiase, Department of Geography, 302 Walker Building, Penn State University, University Park, PA 16802; (814) 863-4562;

Bitnet: dibiase@essc.psu.edu. Coeditor: Karl Proehl, C202 Pattee Library, Penn State University, University Park, PA 16802; (814) 863-0094

\section{INTER-AMERICAN COMMITTEE}

Chair: Jerry Thornton, Map Room,
Harlan Hatcher Graduate Library, University of Michigan, Ann Arbor, MI 48103

\section{MEMBERSHIP COMMITTEE}

Chair: Sona Karentz Andrews,

Department of Geography, University of Wisconsin Milwaukee, Milwaukee, WI 53201; (414) $229-4872$

\section{NOMINATIONS COMMITTEE Chair: Juan José Valdés, Cartographic Division, National Geographic Society, 1615 M Street, N.W., Washington, DC 20036; (202) $775-7873$}

\section{PUBLICATIONS COMMITTEE}

Chair: Alan MacEachren, Department of Geography, 302 Walker Building, The Pennsylvannia State University, University Park, PA 16802; (814) 865-7491; Bitnet: NYB@PSUVM

\section{MINUTES OF THE BOARD MEETING, SATURDAY, FEBRUARY 24, 1990 Orlando, Florida}

Diana Rivera, Fred Fryman, John Sutherland, Craig Remington, Ron Bolton, and Jim Anderson present.

The meeting was called to order by President Rivera at 9:00 a.m. The first order of business was a discussion of local arrangements. Beverly Minor, mapping director for the Orange County elections office, was present for this portion of the meeting as she has volunteered to assist with local arrangements. A discussion was held on field trip possibilities. Possibilities are the Orange County GIS project, AAA, and $\mathrm{a}$ trip around the Orlando area. Fryman and Anderson visited AAA and feel that it would be a very interesting trip. Minor has visited the GIS and they are willing to conduct tours. Anderson will contact the local chamber of commerce about the possibility of a local tour. One suggestion was a behind the scenes tour of Disney World which Minor did not think would be possible, but Anderson will check it out.

Minor will check with the Chamber of Commerce and Convention Bureau on the availability of maps and brochures for the registration packets. Minor will also look into compiling a local restaurant list. 
Anderson will draw a map of the local area to be sent out with pre-registration mailing. Anderson or Minor will also check with the airport authority for shuttle locations and pricing. Also, other local transportation options will be explored.

Anderson asked if any previous registration workers were interested in working in Orlando. Anderson will check with convention bureau on typewriters, etc. Minor will talk to Betty Carter, Supervisor of Elections, about being a speaker or suggesting a speaker, Anderson has contacted NASA about providing a speaker. Fryman will try to contact the St. Petersburg Times cartographer about giving a talk. Bolton suggested the possibility of moving the luncheon to Friday and scheduling a Kennedy Space Center tour for Saturday.

Anderson has agreed to take care of all local arrangements. Question of exhibits was discussed. Sentiment was expressed that Orlando might not draw national exhibits and Bolton said that federal agencies have had their budgets cut and will not be exhibiting. Sutherland suggested providing exhibit space for persons to display materials but not supply persons to staff those exhibits. Rivera stated that members would like to see some form of exhibits. Remington suggested expanding the cart lab poster session to map librarians and geography departments. A committee will be formed to contact government agencies and private agencies about exhibiting.

The next item of business was a general suggestion of the program. Fryman suggested a theme tied to the $90^{\circ} \mathrm{s}$. Anderson suggested a session on cartographic education in the schools. Bolton suggested systems changes in the $90^{\prime} \mathrm{s}$. Anderson suggested a session on census products and reapportionment. Rivera suggested getting out call for papers by mid-March and have May 30 as the deadline for submission of proposals and abstracts. Preliminary programs will be mailed out in August by Anderson. Packet will include preliminary program,

registration forms, airline information and map, and hotel registration form. 'Changing cartography in the 90's the next decade for NACIS was adopted as the conference theme.

Bolton felt that due to job responsibilities he needed to give up the executive officer position. He felt that the board should appoint someone to the position. Persons would need resources for mailing, handling correspondence, answering phone calls, etc. Bolton suggested someone who had been previously on the board. Anderson suggested making the transition after the Orlando meeting. Bolton agreed to serve until then. A decision will be made on a replacement at the summer board meeting.

Bolton felt that a clean version of the constitution and bylaws should be prepared and reviewed by Marsha Selmer and the Board. Anderson will retype and circulate. Copies of the constitution will be available at the annual meeting. Anderson will also check with Greg Chu about putting together a directory.

Greg Chu submitted a written treasurer's report. Chu asked about filing federal tax return. Bolton suggested that the Board empower Chu to pay an attorney or accountant to advise us of our tax status. Board approved. Anderson raised the issue of liability. Rivera will check with other organizations as to how they handle this issue. Bolton asked about reprinting past issues of Cartographic Perspectives as raised in Chu's report. Sutherland felt cost of printing back issues should be borne by people wanting them. Recommendation was made to compliment Chu on his report with an inquiry to be made concerning data base status. Rivera stated some outstanding bills were still due from the Ann Arbor meeting. Anderson suggested compiling new database. Board agreed (Treasurer's report follows).

Bolton mentioned that we would need to elect new vice-president, treasurer, and the board seats of Ellen White and Pat Gilmartin. Bolton recommended that we elect at least three new members to increase attendance at meetings. Anderson suggested looking at people who have run in the past but had not been elected. Several names were suggested and they will be forwarded to Juan Valdés. Bolton stated that we needed to form a separate tellers committee from the nominating committee. Anderson suggested a ballot be mailed out with the registration packet.

Bolton brought up issue of future meetings. A letter from Sona Andrews was circulated with recommendations for the site of the 1991 Milwaukee meeting. Bolton recommended that we give Andrews permission to negotiate a contract with the Astor Hotel. Anderson asked about proposed meeting dates. The hotel is available for any dates in October. Bolton stated that Kansas City had made excellent proposals for 1992, but we didn't have anyone to handle local arrangements. Rivera asked if the Board wanted to consider Costa Rica. Bolton felt that federal employees would not be able to attend. Bolton will begin inquiries in Philadelphia and Minneapolis.

Alan MacEachren submitted a report from the Publications Committee asking for suggestions for publication committee members. Several names were suggested and Rivera will forward names to MacEachren. Rivera proposed a change in editorial structure. Anderson proposed that DiBiase submit proposed structure and let the Board vote yes or no.

Rivera felt that summer board meeting should cover program discussion, other board business, and then discuss long-term planning document for NACIS. She felt that we should continue as we have from year to year or set some long term goals for NACIS's future. She suggested an extended meeting which would involve past presidents to discuss NACIS goals and objectives. Rivera suggested having the meeting at Michigan State. Rivera will survey the past presidents and least five agree to participate the meeting will be held. The Board agreed that $\$ 100$ would be given to each past president to help cover expenses.

There being no further business to discuss the meeting was adjourned at 5:20 p.m.

\section{-James Anderson, secreatary}

\section{TREASURER'S REPORT}

\section{February 22, 1990}

I apologize for not being able to attend this board meeting in Orlando. As I had indicated to Professor Fryman, I am available by long distance phone call (call me collect) at (612) 927-5619 from 12 noon to 6 p.m. (Orlando time) on Saturday. Please call me collect as many times as deemed necessary.

To begin this report, I'd like to announce that I have purchased a very efficient and easy-to-use software that handles mailing and some classification functions. This software will be passed on to succeeding treasurers or secretaries. It is very easy to use, will handle up to 30,000 entries, will help us classify members by categories (institution, individual and student), and will sort ten different fields ( 3 simultaneously). Therefore, I am happy to report that members who have paid their dues are now being entered into this new software. However, I would like to see the old software being kept as a record since there is a large database of about 2000 entries already entered into it. Updating of addresses and new members is done in the new software database.

On January 9, 1990, I sent out the 1990 dues notice not only to 1989 members, but to all names on Jim Anderson's database who have been NACIS members at one time or another. This totaled about 650 entries. In addition, about 100 more names of likely membership candidates were compiled from all U.S. and Canadian graduate schools in geography and added to the mailing. Therefore, About 750 dues notice were sent out. As of today, we have received payment of dues from 15 institutional members, 25 student mem- 
bers, 153 individual members, totaling 193. Fifteen of these 193 are new members (new this year and not counting those who joined before the Ann Arbor meeting). More dues are expected in as I can think of officers and board members who have yet to renew. My estimated final number for this year's membership may reach 350 , but that remains to be seen. The next issue of Cartographic Perspectives will be (may have already been by the time you read this) mailed to all 750 on that list regardless whether they are members or not. The idea was to give away one excellent complimentary issue as a promotional piece in our membership drive and as an announcement of the 'birth of this baby' to the mapping and library community.

The next target for membership drive is map libraries nationwide; not only will they be targeted as institutional members, but their number is quite large. I will have access to this group's mailing list of $900+$ members. A question arises as to whether we can fulfil their requests, DiBiase and I think we can. The question is: if all these map libraries would want Cartographic Prospectives dating back to the first issue, we will have to reprint them to accommodate this block of new members. DiBiase has all issues stored digitally so that reprinting is possible.

As for the financial status of the organization, we managed to consistently keep a buffer of about $\$ 15,000$. As of today, our bank account balance stands at $\$ 18,204.46$ with an expected expenditure of about $\$ 3,500$ for the production of Cartographic Perspectives \#3 and \#4. At the same time, there should be at least 100 members who have yet to pay dues. For our last annual meeting at Ann Arbor, our income from registration and such exceeded all expenditures by about $\$ 900$. It appears, at this point, that the amount of increased dues is just about equal to the added expenditures in the production of Cartographic Perspectives (hats off to Alan MacEachren for coming up with such precise numbers in advance). As our membership grows, I would expect the $\$ 15,000$ buffer to increase, but that also remains to be seen. During the 1989 calendar year, our account yielded $\$ 837.56$ in interest. I am assuming that the bank has already notified IRS that this organization has interest income. It is not clear to me whether we are still listed as non-profit organization; but even if we are not, we do not have an annual income of $\$ 25,000$, therefore, we do not need to pay any tax. The question is whether we still have to file a return. I did not file one last year, maybe Jim Anderson can shed some light on this during his years as treasurer.

To sum it up, we are in good stable financial situation. Our efforts in recruit- ing new members should result in an increased savings. The publication of Cartographic Perspectives has certainly helped boost our image as an organization rising in importance in the mapping field.

- Gregory Chu, treasurer

\section{THE CHANGING POLITICAL MAP OF EUROPE}

continued from page 2

achieving political unity. Not all EEC members are as enthusiastic as France, the primary advocate of the process, and the eventual realization of an integrated Europe is by no means assured. Among the myriad difficulties yet to be worked out, the bitter, generations-old boundary disputes rekindled by nationalist movements threaten to confound the goal of European political and economic unity. In a December, 1989 issue of Le Monde, André Fontaine observed that "The cold war, waged in the name of ideological sympathies, has weakened the thrust of nationalisms. It is the duty of us all to make sure that the end of the cold war does not lead to their revival." sources: Associated Press (Centre Daily Times), New York Times, World Press Review 1/90

\section{EXCHANGE PUBLICATIONS} Cartographic Perspectives gratefully acknowledges the publications listed below, with which we enjoy exchange agreements. We continue to seek agreements with other publications.

\section{Canadian Cartographic Association}

Newsletter. A quarterly publication offering news and announcements to members of the CCA. Contact: Canadian Cartographic Association, c/o Roger Wheate, Department of Geography, University of Calgary, Calgary, Alberts T2N 1N4, Canada; Bitnet:

\section{Wheate@UNCAMULT.}

Cartographica. A quarterly journal endorsed by the Canadian Cartographic Association/Association Canadienne de Cartographie that features articles, reviews and monographs. B V Gutsell, founder and editor. ISSN 0317-7173. Contact: University of Toronto Press Journals Department, 5201 Dufferin Street, Downsview, Ontario, Canada M3H5T8; (416) 667-7781.

\section{Cartographic Journal. Biannual} Journal of the British Cartographic Society. Includes research articles, 'shorter' articles, official records of the Society, book reviews, and list of recent cartographic literature. Contact: Hon. Secretary, Charles Beattie, 13 Sheldrake Gardens, Hordle, Lymington, Hants. SO4 10FJ ENGLAND.

Cartography. Biannual Journal of the Australian Institute of Cartographers. Each issue contains two parts, the Journal proper and the Bulletin. The Journal contains original research papers, papers describing applied cartographic projects, reviews of current cartographic literature and abstracts from related publications. ISSN 0069-0805. Contact: John Payne, Circulation Manager, GPO Box 1292, Canberra, A.C.T. 2601, Australia.

Cartomania. This quarterly newsletter of the Association of Map Memorabilia Collectors offers a unique mix of feature articles, news, puzzles, and announcements of interest to cartophiles. ISSN 0894-2595. Contact: Siegfried Feller, publisher/editor, 8 Amherst Road, Pelham, MA 01002; (413) 253-3115.

Geotimes. Monthly publication of the American Geological Institute. Offers news feature articles, and regular departments including 